WIESŁAW BANACH

\author{
$\stackrel{\circ}{\text { III }}$

\section{MIĘDZY CHINAMI A ZACHODEM. ETOS PRACY JAKO PRZEJAW NOWEJ ODSŁONY „ZDERZENIA CYWILIZACJI"?}

\begin{abstract}
Wiesław Banach, Między Chinami a Zachodem. Etos pracy jako przejaw nowej odsłony „zderzenia cywilizacji"? [Between China and the West. The ethos of work as a manifestation of new version of the "clash of civilizations"] edited by W. Banach, M.A. Michalski, J. Sójka, "Człowiek i Społeczeństwo" vol. XLVI: Między Chinami a Zachodem. Pytanie o źródła chińskiego sukcesu gospodarczego [Between China and the West. An inquiry into the sources of the Chinese economic miracle], Poznań 2018, pp. 121-143, Adam Mickiewicz University. Faculty of Social Sciences Press. ISSN 0239-3271.
\end{abstract}

The purpose of this article is to compare the Chinese and Western value systems in terms of their suitability for economic development. The author focuses on a very important element of every economic culture which is the work ethos. He understands it as a conviction that only hard and systematic work gives the individual the chance to live in relative prosperity. The ethos of work understood in this way is one of the most basic and common cultural habits. It does not arise spontaneously, that is, in a natural way, but it must be developed and cherished, or cultivated. A comparison of the contemporary Eastern and Western work ethos can be helpful in understanding the causes of China's economic success and the declining importance of the West.

These considerations are carried out in the context of Samuel Huntington's 25-year-old thesis about the growing importance of cultural factors in the modern world. According to the author of "Clash of civilizations", such cultural factors as religion, tradition, customs, morality and everything called the system of values are now the source of a deepening global conflict and at the same time increasing economic distance between China and the West.

Wiesław Banach, Uniwersytet im. Adama Mickiewicza w Poznaniu, Wydział Nauk Społecznych, Instytut Kulturoznawstwa, Zakład Etyki Gospodarczej, ul. Szamarzewskiego 89a, 60-568 Poznań, e-mail: banach@amu.edu.pl 


\section{Wprowadzenie}

Mija ćwierć wieku ${ }^{1}$ od czasu postawienia przez Samuela Huntingtona tezy o dominującej roli kultury w świecie, który wyłonił się po upadku komunizmu. Podkreślając rosnące znaczenie szeroko pojętych czynników kulturowych, autor Zderzenia cywilizacji przekonywał wówczas, że większość rodzących się konfliktów swoją genezę będzie miała właśnie w kulturze, a zwłaszcza w jej tradycyjnym jądrze, którym pozostaje religia. „W świecie, jaki nastał po zakończeniu zimnej wojny, flagi bardzo się liczą, to samo dotyczy innych symboli kulturowej tożsamości, takich jak krzyże, półksiężyce, a nawet nakrycia głowy. Liczy się bowiem - jak przekonuje Huntington kultura, a kulturowa tożsamość jest tym, co dla większości ludzi ma najważniejsze znaczenie"2. Sama teza wzbudziła wiele kontrowersji, poszczególne argumenty użyte przez autora na jej poparcie wywołały zaś wiele międzynarodowych dyskusji nie tylko na obszarze nauk politycznych i społecznych. Dyskusjom tym sprzyjało poczucie szczególnego czasu przełomu i potrzeba ujęcia zachodzących w świece zmian w ramy wyjaśniającej je teorii³

${ }^{1}$ Wspomnianą tezę postawił autor w roku 1993, publikując w amerykańskim dwumiesięczniku „Foreign Affairs” artykuł pod tytułem The Clash of Civilizations? (Zderzenie cywilizacji?). Znamienny jest fakt, że tytuł opatrzony był wówczas znakiem zapytania. Jednak w wydanej trzy lata później wersji książkowej, zatytułowanej The Clash of Civilizations and the Remaking of World Order (Zderzenie cywilizacji i nowy kształt ładu światowego), w której Huntington szczegółowo rozwija swoje argumenty, tego znaku zapytania już nie ma. Rezygnacja ta świadczy niewątpliwie o tym, że autor nie tylko podtrzymał swoje wcześniejsze stanowisko, ale także nabrał do niego większego przekonania, czy nawet pewności.

2 S.P. Huntington, Zderzenie cywilizacji i nowy kształt ładu światowego, tum. H. Jankowska, MUZA SA, Warszawa 2004, s. 14.

${ }^{3}$ Nie ma tu, oczywiście, miejsca na choćby skrótowe zreferowanie owych debat i scharakteryzowanie poszczególnych stanowisk, które się wówczas wyłoniły, ale warto wspomnieć, że omawiane wystąpienie Huntingtona stało w opozycji do nie mniej znanego i równie kontrowersyjnego poglądu Francisa Fukuyamy, wyrażonego w eseju z roku 1989 Koniec historii. Myśliciel ten, odwołując się m.in. do filozofii Hegla, przekonywał, że po upadku komunizmu stajemy się świadkami narodzin epoki bez wojen i innych konfliktów, triumfująca zaś demokracja liberalna już na zawsze pozostanie dominującą formą ustrojową zachodnich społeczeństw. W tym sensie oznaczać to będzie, zdaniem autora, tytułowy koniec historii. Por. F. Fukuyama, Koniec historii i ostatni człowiek, tłum. T. Bieroń, M. Wichrowski, Wyd. Znak, Kraków 2017. 
Interesujące wydaje się zweryfikowanie owej tezy w odniesieniu do współczesnej sytuacji międzynarodowej i rodzącego się nowego rozkładu sił w zglobalizowanej gospodarce. Warto mianowicie zastanowić się nad tym, jak poczynione przez Huntingtona przed 25 laty przewidywania jawią się dziś, tj. w okresie, kiedy „gołym okiem” widoczny jest m.in. bezprecedensowy sukces współczesnych Chin. Jest to szczególnie istotne w kontekście słabnącej dominacji świata zachodniego ${ }^{4}$, którego poszczególne gospodarki przeżywają głęboki kryzys. Innymi słowy, niniejszy artykuł stanowi próbę kulturoznawczej refleksji nad przyczynami ekspansji chińskiej gospodarki oraz rodzącym się w związku z tym pytaniem o kulturowe przyczyny tej ekspansji. Czy mianowicie mamy do czynienia z nową odsłoną lub kolejną fazą wojny kulturowej bądź - używając określenia przywołanego autora „zderzenia cywilizacji”? Pytanie brzmi zatem, czy wspomnianą dominację Chin nad Zachodem należy tłumaczyć jedynie wyborem lepszego modelu rozwoju gospodarczego czy też posiadaniem skuteczniej motywującego do pracy systemu wzorów i wartości? Mówiąc wprost, czy jest to kwestia tylko gospodarki czy także kultury?

Jednym z kluczowych elementów aksjologicznego wyposażenia kultury, który „odpowiada” za poziom gospodarczej aktywności jednostek, jest etos pracy. W tym sensie stanowi on istotną część tego, co w refleksji nad wpływem kultury na gospodarkę Max Weber nazywał etyką gospodarczą, a w dzisiejszej literaturze przedmiotu zwie się kulturą gospodarczą. Niniejsze rozważania mają na celu porównanie chińskiego etosu pracy z jego zachodnim odpowiednikiem. Zestawienie to może być przydatne z jednej strony w zrozumieniu przyczyn sukcesu gospodarczego współczesnych Chin, z drugiej zaś - w wytłumaczeniu powodów utraty przez Zachód dominującej pozycji w gospodarce światowej.

\section{"Zderzenie cywilizacji", czyli Huntingtonowska diagnoza współczesności}

Należy na wstępie przywołać najważniejsze elementy omawianej koncepcji Huntingtona, w której prezentuje on swoją diagnozę odnośnie do rzeczywistych przyczyn konfliktów we współczesnym świecie. Nie ma tu miejsca,

\footnotetext{
${ }^{4} \mathrm{~W}$ niniejszym artykule pojęcie Zachodu czy świata zachodniego rozumie się w sensie kulturowym, a nie geograficznym, tzn. jego wyznacznikiem są wyznawane wartości, idee, normy czy prawa, a nie położenie na mapie.
} 
a także potrzeby, aby dokładnie referować stanowisko autora, wyrażone na blisko sześciuset stronicach jego najważniejszej pracy. Zasadne jest jednak wyłuszczenie tych aspektów jego przemyśleń, które ściśle korespondują z tematyką niniejszego artykułu. Otóż główna teza omawianej książki głosi, że „to kultura i tożsamość kulturowa, będąca w szerokim pojęciu tożsamością cywilizacji, kształtują wzorce spójności, dezintegracji i konfliktu w świecie, jaki nastał po zimnej wojnie”5. Z tezy tej wynika zdaniem Huntingtona - kilka nieco bardziej szczegółowych wniosków, spośród których najważniejsze brzmią następująco: globalna polityka przestaje być dwubiegunowa, a nabiera charakteru wielobiegunowej i jednocześnie wielocywilizacyjnej; modernizacja nie jest już tożsama z westernizacją; wpływy Zachodu słabną, zwłaszcza na rzecz cywilizacji azjatyckich, które stają się znaczącymi siłami ekonomicznymi, militarnymi i politycznymi; uniwersalistyczne aspiracje świata zachodniego prowadzą do konfliktów z innymi cywilizacjami, a w szczególności z islamem i Chinami; w świecie islamu mamy do czynienia z demograficzną eksplozją, która destabilizuje region oraz kraje sąsiednie; cywilizacje niezachodnie, budując własną tożsamość, poszukują na nowo potwierdzenia wartości swoich kultur; kraje o zbliżonych kulturach grupują się wokół państw stanowiących ośrodki ich cywilizacji i znajdują wspólną platformę współdziałania; próby przenoszenia społeczeństw z jednej cywilizacji do drugiej skazane są na niepowodzenie; przetrwanie cywilizacji zachodniej zależy od tego, czy jej mieszkańcy zjednoczą się, „by tchnąć w nią nowego ducha”, Amerykanie zaś ponownie potwierdzą swą zachodnią tożsamość́.

Z samego tytułu książki Huntingtona, czy też z przywołanej powyższej krótkiej charakterystyki problemów, którymi się zajmuje, widać wyraźnie, że centralnym pojęciem jego koncepcji jest cywilizacja. To właśnie cywilizacja stanowi najbardziej obszerny komponent świata społecznego, z którym identyfikuje się jednostka ludzka. Jest ona „najwyższym kulturowym stopniem ugrupowania ludzi i najszerszą płaszczyzną kulturowej tożsamości, ponad którą jest już tylko to, co odróżnia człowieka od innych gatunków. [...] Cywilizacje - kontynuuje autor - to największe my, grupy, w ramach których czujemy się pod względem kulturowym jak w domu, w odróżnieniu od wszystkich innych on y ch"7. Huntington używa pojęcia cywilizacji

${ }^{5}$ S.P. Huntington, op. cit., s. 15.

${ }^{6}$ Por. S.P. Huntington, op. cit., ss. 15-16.

${ }^{7}$ Ibidem, s. 51. Autor wyróżnia osiem głównych cywilizacji współczesności. Są to cywilizacje: chińska, japońska, hinduistyczna, islamska, prawosławna, zachodnia, latynoamery- 
w liczbie mnogiej, tzn. uważa, że twierdzenie, jakoby istniała jakaś jedna, uniwersalna cywilizacja światowa, jest bezzasadne. Ponadto przyjmuje założenie podzielane wszędzie poza Niemcami ${ }^{8}$, że „,cywilizacja jest największą jednostką kulturową”. Oznacza to, iż poszczególne społeczności i grupy zamieszkujące określony obszar, połączone różnymi więzami (np. etnicznymi, językowymi, narodowościowymi czy religijnymi) są uczestnikami odrębnych kultury o rozmaitym stopniu zróżnicowania. „Kultura wsi na południu Włoch - tłumaczy Huntington - może się różnić od kultury wsi z północy tego kraju, ale mają wspólne cechy charakterystyczne dla kultury włoskiej i pod tym względem są odmienne od wsi niemieckich. Społeczności europejskie mają wspólne cechy odróżniające je od społeczności hinduskich czy chińskich, ale Chińczycy, Hindusi i ludzie Zachodu nie należą do żadnej szerszej wspólnoty kulturowej. Są członkami cywilizacji”. Zdaniem autora tytułowe zderzenie nastąpi nie tyle pomiędzy kulturami, stanowiącymi części tej samej cywilizacji, ale właśnie pomiędzy wielkimi cywilizacjami. To właśnie te konflikty stanowić będą w najbliższej przyszłości największe zagrożenie dla globalnej stabilizacji i światowego ładu. „Najostrzejsze, najpoważniejsze i najgroźniejsze konflikty - w opinii Huntingtona - nie będą się w tym nowym świecie toczyć między klasami społecznymi, biednymi i bogatymi czy innymi grupami zdefiniowanymi w kategoriach ekonomicznych, ale między ludami należącymi do różnych kręgów kulturowych. W ramach poszczególnych cywilizacji będą wybuchały konflikty plemienne i etniczne. Jednakże walka między państwami i grupami należącymi do różnych cywilizacji grozi potencjalną eskalacją, bo inne państwa i grupy spieszą na pomoc krajom pokrewnym”10. Próby scalania, łączenia czy dokonywania społecznych, politycznych, a przede wszystkim kulturowych syntez mogą przynieść powodzenie jedynie w ramach tej samej cywilizacji. Wszelkiego typu hybrydy cywilizacyjne prędzej czy później skazane

kańska i - z pewnymi zastrzeżeniami - cywilizacja afrykańska. Por. ibidem, ss. 54-59. W innym miejscu (s. 21) cytowanej książki autor prezentuje mapę cywilizacji na świecie po roku 1990, na której - poza wymienionymi powyżej - umieścił też cywilizację buddyjską.

${ }^{8}$ Huntington sprzeciwia się rozróżnieniu wprowadzonemu na gruncie XIX-wiecznej humanistyki niemieckiej, zgodnie z którym mamy do czynienia z dwoma oddzielnymi bytami: z jednej strony z cywilizacją (technika, czynniki materialne itp.), z drugiej zaś - z kulturą (wartości, ideały, moralność itp.). Podziela w tym zakresie stanowisko Fernanda Braudela, który - jak większość badaczy - kwestionuje możliwość oddzielania na sposób niemiecki kultury od jej bazy, jaką jest cywilizacja. Por. ibidem, s. 48.

${ }^{9}$ Ibidem, s. 51.

${ }^{10}$ Ibidem, s. 20. 
są na niepowodzenie, a ponadto stanowić mogą zarzewie realnego i głębokiego konfliktu na skalę światową. Innymi słowy, w polityce światowej miejsce rywalizacji zwaśnionych supermocarstw znajdujących się po obu stronach żelaznej kurtyny zajmie teraz starcie cywilizacji.

W zrozumieniu Huntingtonowskiego sposobu pojmowania cywilizacji istotne jest uświadomienie sobie znaczenia, jakie w swojej koncepcji autor przypisuje religii. Otóż według Huntingtona „religia to centralny element definiujący cywilizację"11. To nie organizacja polityczna w postaci państwa, rasa czy język stanowią główny komponent cywilizacji. Jest nim religia i związany z nią system wartości. Co więcej, w ostatnim okresie uwidocznił się szczególnie na obszarach niezachodniego świata swoisty powrót do korzeni. Polega on na rosnącym znaczeniu religii, która - według autora - coraz częściej zastępuje dominujące wcześniej ideologie. Zwłaszcza w krajach azjatyckich oraz rejonach opanowanych przez islam widoczne jest przejmowanie przez organizacje religijne dotychczasowych funkcji państwa. Ich mieszkańcy dostrzegają wymierne korzyści tego stanu rzeczy, budując swoją tożsamość i poczucie bezpieczeństwa nie wokół instytucji państwowych, ale właśnie wokół religii, która w ten sposób staje się motorem rozwoju. „Jesteśmy świadkami końca epoki postępu, stojącej pod znakiem zrodzonych na Zachodzie ideologii [...]. Ten globalny proces powrotu do korzeni przejawia się w ożywieniu religii, które ma miejsce w tak wielu rejonach świata, w sposób zaś najbardziej znamienny widać go w kulturalnym odrodzeniu w Azji i krajach islamskich”12. Zdaniem Huntingtona coraz wyraźniej widać, że rozum nie wystarcza ludziom do ży cia, a próby tworzenia świeckich ersatzów religii i tradycyjnie ukształtowanych systemów wartości skończyły się niepowodzeniem. Nie oznacza to bynajmniej odrzucenia samej idei modernizacji. Kraje niezachodnie odchodzą po prostu od bezrefleksyjnego imitowania instytucji, społecznych rozwiązań, praw i liberalnych wartości, które w przeszłości zapewniły Zachodowi hegemonię. Współcześnie stały się one dla nich całkowicie nieatrakcyjne, a często - w ich przekonaniu - wręcz szkodliwe. Mówiąc nieco bardziej precyzyjnie, społeczeństwa niezachodnie ochoczo i bez ograniczeń korzystają z dobrodziejstw (zwłaszcza nowoczesnych technologii ${ }^{13}$ )

11 Ibidem, s. 59.

12 Ibidem, s. 145.

13 Opisując to zjawisko, Huntington wskazuje na swego rodzaju paradoks polegający na tym, że nawet jawni wrogowie Zachodu dla propagowania swoich idei i poglądów posługują się nowoczesnymi technologiami stanowiącymi wytwór zachodniej cywilizacji. 
stworzonych przez Zachód, ale odrzucają ulegający erozji zachodni system wartości. Dlatego też „modernizacja nie musi koniecznie oznaczać westernizacji. Niezachodnie społeczeństwa mogą się modernizować i - jak przekonuje autor - czyniły to, nie odrzucając swojej kultury i nie przyjmując hurtem zachodnich wartości, instytucji i zwyczajów” ${ }^{14}$. W kontekście tego odrzucenia nietrudno zrozumieć twierdzenie Huntingtona o powolnym, aczkolwiek systematycznym zmierzchaniu zachodniej cywilizacji. Wpływy Zachodu znacząco zanikają i współcześnie coraz trudniej jest mówić zwłaszcza o jego kulturowej hegemonii. Unikatową i szczególną cechą każdej cywilizacji jest długowieczność i odporność na różnego rodzaju zawirowania, którym ulegają organizmy państwowe i inne mniejsze struktury. Jednak i te - jak stwierdza autor - najdłużej trwające zrzeszenia ludzi są śmiertelne: „W swoim trwaniu cywilizacje również ewoluują. Są dynamiczne: mają swoje wzloty i upadki, łączą się i dzielą [...], zanikają i zostają pogrzebane pod piaskami czasu”15.

W nawiązaniu do omówionej powyżej koncepcji Huntingtona warto zastanowić się nad źródłami niewątpliwego sukcesu ekonomicznego i rosnących wpływów cywilizacji chińskiej, a jednocześnie uświadomić sobie przyczyny współczesnego kryzysu cywilizacji zachodniej. Patrząc na tę koncepcję z perspektywy minionego ćwierćwiecza, które upłynęło od czasu jej przedstawienia, można pokusić się nie tyle o wyciąganie daleko idących wniosków w postaci kategorycznych twierdzeń, ile raczej o dokonanie „okresowego przeglądu” spraw podejmowanych przez autora Zderzenia cywilizacji. Nie ma tu, oczywiście, miejsca na dogłębną analizę i ocenę poszczególnych twierdzeń Huntingtona, a także potrzeby określania, w jakim stopniu znalazły one potwierdzenie w politycznych wydarzeniach i społecznych trendach, których jesteśmy dziś świadkami. Wydaje się jednak, że zaproponowany przez omawianego autora u schyłku zimnej wojny sposób interpretacji światowych procesów oraz jego zapowiedzi odnośnie

14 Ibidem, s. 115. W innym miejscu (s. 157) omawianej książki Huntington pisze na temat odrzucenia zachodniego systemu wartości w sposób znacznie bardziej dosadny: „odrodzenie niezachodnich religii jest najbardziej dobitnym przejawem antyzachodniości w społeczeństwach innych kręgów kulturowych. Odrodzenie to nie oznacza odrzucenia nowoczesności, jest natomiast odrzuceniem Zachodu oraz kojarzonej z nim świeckiej, relatywistycznej i zdegenerowanej kultury. To niezgoda na zjawisko, które określano mianem westtoksyfikacji, zatrucia Zachodem. To deklaracja kulturowej niezależności od Zachodu, dumne oznajmienie, że staniemy się nowocześni, ale nie będziemy wami”.

15 Ibidem, s. 52. 
do czekających nas zmian miały dużą wartość i moc prognostyczną. Sam Huntington miał świadomość, że w nowej rzeczywistości, która nastała po upadku komunizmu, niezbędne jest stworzenie koncepcji nie tylko lepiej od innych objaśniającej zachodzące w świecie zmiany, ale również przewidującej, co nas czeka w przyszłości. Postulowana koncepcja prognozująca kulturowy charakter nadchodzących konfliktów stanowi dla jej autora nowy paradygmat w naukach społecznych oraz mapę, za pomocą której będziemy w stanie orientować się w swoim położeniu. Zaproponowane przez siebie podejście metodologiczne nazywa wprost paradygmatem cywilizacyjnym ${ }^{16}$. Należy zaznaczyć, że Huntington, prezentując omawianą koncepcję, przewidział nie tylko ogólne trendy, tendencje czy kierunki zmian, których jesteśmy dziś świadkami, ale także wiele dość szczegółowych i konkretnych wydarzeń. Za ilustrację możliwości prognostycznych jego koncepcji niech posłuży przykład wojny na Ukrainie. Omawiany autor nie tylko przepowiedział konflikt rosyjsko-ukraiński, ale i to, że jego główną linią demarkacyjną będzie granica kulturowa, a mówiąc dokładniej - religijna. Otóż najtrwalszą i najsilniejszą granicą funkcjonującą od wieków na tym terenie jest ta, która oddziela prawosławną, prorosyjską Ukrainę wschodnią od ciążącej ku Zachodowi, unickiej Ukrainy zachodniej. Huntington wyraźnie podkreśla, że możliwy jest trwały rozpad Ukrainy na dwie części za sprawą oddziaływania czynników kulturowych w oparciu o tę właśnie granicę ${ }^{17}$.

\section{Historyczne i kulturowe uwarunkowania gospodarki chińskiej}

W niniejszym punkcie omówione zostaną wybrane kwestie dotyczące przyczyn chińskiego sukcesu gospodarczego. Istnieje wiele opracowań i analiz,

16 Ibidem, ss. 24-27. Zaproponowane przez siebie podejście traktuje Huntington nie tylko jako nowatorskie, ale wręcz rewolucyjne. Odwołuje się wprost do klasycznej pracy Thomasa Kuhna Struktura rewolucji naukowych i podkreśla konieczność stworzenia nowego modelu rozumienia społecznej i politycznej rzeczywistości, polegającego na „zastąpieniu jednego paradygmatu, który coraz mniej potrafi wyjaśnić nowe lub nowo odkryte fakty, przez inny, lepiej owe fakty uwzględniający” (ibidem, s. 24).

17 Por. ibidem, s. 39. Bez wątpienia, istotnym wytłumaczeniem dla tak dużego znaczenia i doniosłości, jakie przypisuje Huntington wspomnianej granicy, jest wyodrębnianie w ramach jego koncepcji oddzielnej cywilizacji prawosławnej, której ośrodek stanowi Rosja. Autor charakteryzuje ją w następujący sposób: „Od zachodniego chrześcijaństwa odróżnia ją bizantyjski rodowód, odrębna religia, dwieście lat panowania tatarskiego, biurokratyczny despotyzm oraz ograniczony kontakt z Renesansem, Reformacją, Oświeceniem i innymi zjawiskami tak ważnym dla Zachodu” (ibidem, s. 56). 
zwłaszcza o charakterze ekonomicznym czy politologicznym, które starają się udzielić mniej lub bardziej złożonych odpowiedzi na pytania o tajemnice współczesnej chińskiej prosperity. Jesteśmy bowiem świadkami rosnącego znaczenia, a w niektórych dziedzinach wręcz dominacji Chin, które stały się światowym mocarstwem. Znamienny jest fakt, że osiągnęły to kosztem przede wszystkim Stanów Zjednoczonych oraz innych wiodących krajów Zachodu. Zanim jednak dokona się analizy współczesnej sytuacji i podejmie próbę odpowiedzi na pytania o genezę chińskiego boomu gospodarczego ostatnich dekad, warto poświęcić nieco uwagi naukowym dyskusjom na temat przeszłości Chin.

Za klasykę badań sinologicznych uchodzą na gruncie nauk społecznych porównania Webera, który - dokonując przeglądu światowych religii, w tym konfucjanizmu i taoizmu - starał się ustalić, jaki „klimat” stwarzają one dla podejmowania przez jednostki działalności gospodarczej. Interesujące - zwłaszcza w kontekście podejmowanych w niniejszym artykule rozważań - jest to, że omawiany autor, zajmując zdecydowanie europocentryczne stanowisko, wskazuje na różnego rodzaju mankamenty i deficyty pozaeuropejskich kultur, które uniemożliwiły im osiągnięcie gospodarczego sukcesu. Autor podkreśla fundamentalne znaczenie racjonalności jako dystynktywnej cechy kultury Zachodu, która u progu nowożytności pozwoliła mu wejść na nieosiągalną dla innych drogę kapitalistycznego rozwoju. Owa racjonalność to efekt tzw. „odczarowania świata”, które w konsekwencji rozprzestrzenienia się protestanckich idei stało się udziałem jedynie kultury zachodniej. Braki te dostrzega Weber także w odniesieniu do kultury Chin. Jego zdaniem takie elementy, jak: system religijny, moralność, tradycje, obyczajowość, prawo, etatyzm czy brak mieszczaństwa itp. stanowiły główną przeszkodę na drodze do stworzenia w Chinach nowoczesnego państwa i gospodarki kapitalistycznej. Jako ilustrację totalitarnego charakteru chińskiego państwa i wadliwości jego systemu politycznego przywołać można znamienny fragment pracy Webera Konfuzianismus und Taoismus z roku 1916, w którym autor opisuje zjawisko wszechobecnego mieszania się sfery religijnej z polityką: „Jeszcze w 1455 r. jeden z cesarzy udzielił duchowi góry Tai oficjalnej nagany. A w innych wypadkach duchy takie pozbawiano kultu i ofiar. Racjonalista wśród wielkich cesarzy i zjednoczyciel państwa, Shi Huangdi, kazał - jak podaje w jego biografii Sima Qian - ogołocić za karę z roślinności górę, której duch stawił mu opór i utrudniał do niej dostęp”"18.

${ }^{18}$ M. Weber, Taoizm i konfucjanizm, w: idem, Socjologia religii. Dzieła zebrane. Etyka gospodarcza religii światowych, cz. 1, tłum. T. Zatorski, Zakład Wydawniczy Nomos, Kraków 2006, s. 35. 
Stanowisko podobne do Weberowskiego w omawianej kwestii deficytów cywilizacji chińskiej zajmuje współcześnie David S. Landes. W cennej z punktu widzenia podejmowanej tu tematyki książce Bogactwo i nędza narodów. Dlaczego jedni sq tak bogaci, a inni tak ubodzy autor przywołuje liczne argumenty potwierdzające tezę Webera o kulturowych, czy szerzej - pozaekonomicznych, źródłach chińskiego zacofania względem Zachodu. Długa lista chińskich wynalazków, takich jak: „taczka, strzemię, sztywne chomąto (zapobiegające duszeniu się konia), kompas, papier, druk, proch strzelniczy, porcelana”"19, to dla autora przejaw wielkich możliwości, jakimi dysponował ten kraj na przestrzeni wieków. Niestety, w przeszłości potencjał ten nigdy nie został w pełni wykorzystany i Chiny nie były w stanie przeciwstawić się gospodarczej czy cywilizacyjnej dominacji Zachodu. Zastanawiając się nad tym paradoksem, Landes podąża śladem Webera i tłumaczy ten stan rzeczy wieloma wadami chińskiego systemu wartości oraz ograniczeniami instytucjonalnymi. Pomimo że Chińczycy dysponowali wiedzą, umiejętnościami oraz zaawansowanymi technologiami, nie odnotowano w ich kraju (z wyjątkiem rolnictwa) trwałego postępu technologicznego i - co ważniejsze - nigdy nie miała tam miejsca rewolucja przemysłowa na wzór zachodni ${ }^{20}$. Rzecz w tym, że Chińczykom brakowało nie tyle elementów czy instytucji sprzyjających gospodarowaniu (wolny rynek, prawo własności, nowożytna nauka, swoboda gospodarcza itd.), ile raczej europejskiej mentalności. Wszechobecny bezruch, tradycjonalizm i rutyna w połączeniu ze sprawowaną przez państwo całkowitą kontrolą, nadzorem i cenzurą powodowały, że brak było tam tak charakterystycznej dla Europejczyków manii naprawiania i ulepszania²1.

19 D.S. Landes, Bogactwo i nędza narodów. Dlaczego jedni sq tak bogaci, a inni tak ubodzy, tłum. H. Jankowska, MUZA SA, Warszawa 2000, s. 77. Autor ten podaje wiele przykładów, które świadczyć mają o przewadze w cywilizacyjnym rozwoju Chin nad Europą, zwłaszcza w epoce średniowiecza. Jak przekonuje: „chiński przemysł tekstylny i hutniczy znacznie wyprzedzał europejski - Chińczycy posługiwali się napędzaną siłą wody maszyną do przędzenia konopi już w XII wieku. Dopiero pięćset lat później, w okresie rewolucji przemysłowej, w Anglii weszły w użycie tzw. ramy wodne typu muł. Wcześnie też (podobno) nauczyli się używać węgla i koksu w piecach do wytopu żelaza i pod koniec XI wieku produkowali już 125 tysięcy ton surówki. Wielka Brytania osiągnęła ten poziom produkcji po siedmiuset latach” (ibidem, s. 78).

${ }^{20}$ Wśród badaczy omawianego problemu panuje w zasadzie zgoda, że do czasu wybuchu rewolucji przemysłowej, czyli do drugiej połowy XVIII w., Chińczycy posiadali w swoich rękach wszystkie elementy niezbędne do tego, aby ta rewolucja u nich wybuchła. Spory dotyczą raczej odpowiedzi na pytanie, dlaczego tak się nie stało.

${ }^{21}$ Fatalna w skutkach była, zdaniem Landesa, zwłaszcza polityka chińskiego państwa wobec handlu morskiego, które świadomie i celowo ograniczało wszelkie inicjatywy 
Zdaniem Landesa odpowiedź na oczywiste w tym kontekście pytanie, dlaczego Chinom się nie udało, jest bardzo złożona. Zapewne wpływ na gospodarczą historię Chin miało - oprócz wskazanych powyżej deficytów wiele innych czynników, spośród których najczęściej wskazuje się na słabe wykorzystywanie osiągnięć rodzimej nauki i techniki przy jednoczesnym odrzuceniu cudzoziemskiej technologii i zamknięciu się na osiągnięcia innych cywilizacji. Negatywną rolę odegrała ponadto chińska megalomania oraz swoisty triumfalizm kulturowy. W opinii Landesa to one w znacznej mierze spowodowały, że „Chiny niechętnie cokolwiek poprawiały i kiepsko się uczyły”22. Ich protekcjonalizm ujawniał się - jak przekonuje autor zwłaszcza w kontaktach z cudzoziemcami: „Państwo Środka - już ta nazwa mówi sama za siebie - uważało się za najważniejszą jednostkę polityczną świata: pierwszą pod względem rozmiarów i liczby ludności, a także wieku i doświadczenia, niezrównaną, jeśli chodzi o osiągnięcia kultury oraz poczucie moralnej, duchowej i intelektualnej wyższości. Chińczycy byli przekonani, że żyją w samym środku wszechświata. Otaczające ich niższe rasy pławiły się w ich blasku, zyskiwały status, okazując im posłuszeństwo i składając daniny”23.

Odmienne stanowisko w kwestii oceny przydatności chińskiego systemu wartości w osiąganiu przez ten kraj sukcesów gospodarczych zajmuje Kazimierz Poznański. W swoich publikacjach na ten temat skupia się głównie na interpretacji religii konfucjańskiej jako istotnym stymulatorze aktywności gospodarczej Chińczyków i źródle ich współczesnych sukcesów. Należy podkreślić, że dokonuje tego w taki sposób, aby nie tylko skontrastować ją z ekonomią świata zachodniego, ale również wykazać wyższość konfucjańskiego podejścia do ekonomii nad podejściem liberalnym. Jego zdaniem to właśnie konfucjańskie ujęcie refleksji ekonomicznej stoi nie tylko za minionymi osiągnięciami cywilizacji chińskiej, ale - co bardziej istotne stanowi także decydujący element współczesnego sukcesu gospodarczego Chin. Na przestrzeni dziejów religia konfucjańska jak żadna inna myśl

w tym zakresie: „Szczególnie prześladowano handel morski, uznany w Państwie Środka za odstępstwo od celów imperium, czynnik rozłamowy i źródło nierówności w dochodach, a także, co gorsza, pretekst do opuszczania kraju. Osiągnęło to apogeum za dynastii Ming (1368-1644), kiedy państwo próbowało zakazać wszelkiego handlu z zagranicą. Zakazy omijano, rozwinął się przemyt, a wraz z nim korupcja (opłacanie się urzędnikom), konfiskaty, przemoc i kary. Władza tłumiła inicjatywę, koszty transakcji rosły, a ludzie utalentowani stronili od handlu i przemysłu" (ibidem, s. 79).

${ }^{22}$ Ibidem, s. 379.

${ }^{23}$ Ibidem, s. 378. 
kształtowała chińską kulturę i chiński sposób myślenia. Chińczycy nigdy całkowicie z niej nie zrezygnowali. Nawet marksistowska indoktrynacja i komunistyczny terror związany z przymusową industrializacją po 1949 r. nie zdołały wyrugować jej z chińskiej mentalności. „Od 1978 roku, jako gospodarka w okresie transformacji, Chiny stopniowo wycofują zaadoptowany w 1949 roku model sowiecki i zastępują go ekonomią konfucjańską, która ma stanowić strategię docelową. Starożytne konfucjańskie podejście do gospodarki stało się w ten sposób siłą napędową chińskiej nowoczesności. Stanowi to - pisze autor - główną przyczynę chińskiego cudu gospodarczego lub inaczej mówiąc, najdłuższej hossy w nowożytnej historii”24.

Na podstawie lektury prac Konfucjusza, a zwłaszcza jego ucznia Mencjusza, rekonstruuje Poznański główne założenia chińskiej ekonomii i przeciwstawia je aksjomatom zachodniej ekonomii klasycznej. W celu czytelnej ilustracji swoich poglądów na odmienność obu typów ekonomii posługuje się autor zestawieniem w formie tabeli.

Tabela. Podstawowe założenia: ekonomia konfucjańska a ekonomia klasyczna

\begin{tabular}{|l|l|l|}
\hline \multicolumn{1}{|c|}{ Wyszczególnienie } & \multicolumn{1}{c|}{ Ekonomia konfucjańska } & \multicolumn{1}{c|}{ Ekonomia klasyczna } \\
\hline 1. Podstawowy cel & Ciągłość (prokreacja) & Konsumpcja (egzystencja) \\
\hline 2. Dostępność zasobów & Obfitość (nadmiar) & Rzadkość (deficyt) \\
\hline 3. Strategia przetrwania & Pilna praca & Zdobywanie zasobów \\
\hline 4. Główna motywacja & Nastawienie moralne & Prawa własności \\
\hline 5. Podstawowa instytucja & Rodzina & Wolny rynek \\
\hline 6. Dystrybucja dochodu & Równość (brak ubóstwa) & $\begin{array}{l}\text { Nierówność (obecność } \\
\text { ubóstwa) }\end{array}$ \\
\hline 7. Uprawnienia państwa & Państwo merytokratyczne & Państwo minimalne \\
\hline 8. Preferowana metoda & Zdrowy rozsądek & Modele teoretyczne \\
\hline
\end{tabular}

Źródło: K. Poznański, op. cit., s. 88.

Nie ma tu miejsca na omawianie kolejnych punktów powyższego zestawienia, a tym bardziej przywoływanie szczegółowych uzasadnień autora. Z punktu widzenia niniejszego artykułu istotne wydaje się jednak wskazanie na kilka elementów omawianej koncepcji, które - w opinii Poznańskiego - świadczyć mają o specyfice chińskiego podejścia do ekonomii, które

${ }^{24}$ K. Poznański, Ekonomia jako etyka: podejście konfucjańskie, tłum. M.A. Michalski, w: E. Mączyńska, J. Sójka (red.), Etyka i ekonomia. W stronę nowego paradygmatu, PTE, Warszawa 2017, s. 115. 
nazywa on ekonomią konfucjańską. Istnieje ona nie tyle w podręcznikach akademickich czy salach wykładowych (bo - jak podkreśla Poznański - większość chińskich ekonomistów nadal uzyskuje wykształcenie na zachodnich uczelniach), ile raczej w „ludzkich umysłach”, ukształtowanych przez wieki przez chińską kulturę, a zwłaszcza filozofię konfucjańską. Pierwszym takim elementem, stanowiącym główną różnicę pomiędzy ekonomią konfucjańską a jej zachodnią odpowiedniczką, jest to, że o ile ta pierwsza koncentruje się na rodzinie, o tyle ta druga - na samodzielnej jednostce. W podejściu konfucjańskim to właśnie rodzina stanowi nie tylko kluczowe pojęcie czy podstawową kategorię badawczą, ale przede wszystkim punkt wyjścia, warunkujący zrozumienie istoty ekonomii konfucjańskiej. „Celem jednostki jako członka rodziny jest raczej troska o ciągłość rodu lub dziedzictwo, a nie, jak to zakłada liberalizm, natychmiastowa gratyfikacja. Tym, co według konfucjanistów motywuje jednostki, jest odpowiedzialność moralna za innych, przede wszystkim za rodzinę, podczas gdy w podejściu liberalnym jednostka kieruje się poczuciem prawa własności. Ponieważ kluczowe wybory moralne dokonywane są w rodzinie (np. narodziny dziecka w perspektywie ciągłości pokoleniowej), to ona, a nie rynek, jest podstawową instytucją"25. Konfucjańska koncentracja na ciągłości życia, szczególnie w ramach rodziny, wymusza przyjmowanie dłuższej perspektywy (opóźnionej gratyfikacji), zachęcając tym samym do większego oszczędzania i odsunięcia w czasie konsumpcji ${ }^{26}$.

Ta ostatnia kwestia wiąże się z najistotniejszą z punktu widzenia niniejszego artykułu kategorią, jaką jest chiński etos pracy. W kulturze chińskiej, a zwłaszcza filozofii konfucjańskiej, praca zawsze stanowiła niezmiernie ważny element. Postrzegana była jako jedyne źródło bogactwa. Co więcej, dla wielu Chińczyków praca była często także znaczącym źródłem satysfakcji i radości. Można nawet powiedzieć, że była wartością samą w sobie czy - jak pisze Poznański - stanowiła dobro duchowe. Człowiek - zgodnie z chińską tradycją - aby w pełni zaspokoić swoje potrzeby i zrealizować plany, powinien zająć się taką pracą, która nie tylko jest zgodna z jego możliwościami i preferencjami, ale którą przede wszystkim - mówiąc

\footnotetext{
${ }^{25}$ Ibidem, s. 83.

${ }^{26}$ Myśl tę zdają się potwierdzać dane przywoływane przez ekonomistów. W jednym ze swoich tekstów dotyczących potencjału współczesnych Chin, a zwłaszcza możliwości inwestycyjnych ich gospodarki, Grzegorz Kołodko pisze: „Podczas gdy Amerykanie oszczędzają 17,6 procent swego dochodu narodowego (mieszkańcy UE 21,4 procent), to Chińczycy - aż 46 procent” (G. Kołodko, Czy Chiny zbawiq świat, „Rzeczpospolita” 16.05.2017, s. B4).
} 
wprost - kocha. Warunkiem osiągnięcia życiowego spokoju oraz harmonii jest wybór przez niego takiego zawodu, który wykonywany będzie z powołania. Nie bez przyczyny Chińczycy zawsze nienawidzili jakichkolwiek form uchylania się od pracy czy lenistwa, a nawet mieli tendencję do pracowania więcej, niż w rzeczywistości potrzebowali ${ }^{27}$. Omawiany autor podkreśla, że ten swoisty kult pracy utrwalony został w chińskiej świadomości na przestrzeni wieków w efekcie dominacji konfucjańskiego podejścia do życia. Poznański nie poprzestaje jednak na analizach historycznych i podnosi kwestię stosunku współczesnych Chińczyków do pracy. Zapytuje zatem, „,czy istnieje jakiś dowód na to, że dzisiejsze Chiny podążają śladem konfucjańskiego - »purytańskiego « w duchu - stosunku do pracy? Odpowiedź brzmi, że są liczne dowody na to, że traktowana poważnie, uczciwa praca jest uważana przez ludzi za sposób życia, często nawet za sens życia. Każdy odwiedzający może to zobaczyć w dzisiejszych Chinach, gdzie ludzie przeważnie zaczynają pracę o godzinie 8-9 i są w niej do późna, nawet do godziny 22. Pracują także w soboty, nawet mimo że nie tak dawno - zostały one w Chinach wprowadzone jako dni wolne" 28 .

\section{Między Chinami a Zachodem, czyli o znaczeniu etosu pracy jako podstawowego mechanizmu kultury}

Jak już zostało wspomniane na wstępie, jednym z głównych celów niniejszego artykułu jest porównanie chińskiego etosu pracy z jego zachodnim odpowiednikiem. Takie zestawienie przyczynić się może do pełniejszego zrozumienia przyczyn sukcesu gospodarczego współczesnych Chin przy jednoczesnej utracie przez Zachód pozycji hegemona. Etos pracy jest bowiem jednym z kluczowych elementów aksjologicznego wyposażenia kultury, który „odpowiada” za poziom gospodarczej aktywności jednostek. W tym sensie stanowi on istotną część tego, co w refleksji nad wpływem kultury na gospodarkę Weber nazywał etyką gospodarczą, a w dzisiejszej literaturze przedmiotu określa się jako kulturę gospodarczą ${ }^{29}$.

\footnotetext{
27 Por. K. Poznański, op. cit. s. 93.

28 Ibidem, ss. 111-112.

${ }^{29}$ Godną polecenia pozycją, która w sposób bardzo rzeczowy i wyczerpujący omawia kwestie związane z kulturą gospodarczą, jest książka Petera Bergera Rewolucja kapitalistyczna. Autor, który uważa się za spadkobiercę i kontynuatora myśli Webera, przez kulturę gospodarczą rozumie „społeczno-kulturowy kontekst aktywności gospodarczej i funkcjonowanie instytucji gospodarczych”, a kierując Instytutem Studiów nad Kulturą
} 
Samo pojęcie etosu używane jest zarówno w dyskursie naukowym, jak i w języku potocznym. Znane jest od czasów starożytnej Grecji, gdzie ethos oznaczał zwyczaj. Za sprawą Arystotelesa wiemy, że etos nie jest wytworem naturalnym, ale społecznym ${ }^{30}$ czy - jak powiedzielibyśmy współcześnie - kulturowym. W tym klasycznym ujęciu przez etos rozumie się obowiązujące i realizowane w danej grupie czy zbiorowości ludzkiej określone ideały, obyczaje, normy i wzory postępowania. Istotne jest to, aby przekładały się one na zachowania społeczne. Owo przełożenie wartości na działania oznacza, że członkowie grup muszą nie tylko utożsamiać się z obowiązującym systemem wartości, ale także stosować się do niego w praktyce życia codziennego. W tym sensie etos stanowi swego rodzaju zaangażowanie ludzi w określone wzory zachowań społecznych ${ }^{31}$.

W każdej kulturze obecne są pewne niekwestionowane wartości, normy, wzorce i postawy, które odnoszą się do pracy i stosunku do niej jednostki ludzkiej. Składają się na jej etos pracy. To właśnie dzięki niemu ludzkość od swego zarania może pomnażać materialny i niematerialny dorobek oraz twórczo przekształcać otaczający świat. Tak rozumiany etos pracy stanowi jeden z najbardziej podstawowych i powszechnych nawyków kulturowych. Nie powstaje on samoczynnie, czyli w sposób naturalny, ale trzeba go wykształcić i pielęgnować, czyli uprawiać32 . Ważne jest, aby w opisywanym tu podejściu do etosu pracy postrzegać go zawsze w kontekście kultury, czy wręcz utożsamiać go ze swego rodzaju mechanizmem obecnym w każdej

Gospodarczą przy Uniwersytecie Bostońskim (Institute for the Study of Economic Culture at Boston University), jest orędownikiem badań, które powinny się stać przedmiotem tzw. kulturoznawstwa gospodarczego. Por. P.L. Berger, Rewolucja kapitalistyczna, tłum. Z. Simbierowicz, Oficyna Naukowa, Warszawa 1995, s. 20.

${ }^{30}$ Por. Arystoteles, Etyka nikomachejska, tłum. D. Gromska, Państwowe Wydawnictwo Naukowe, Warszawa 1982, s. 43.

${ }^{31}$ Por. W. Molik, Etos Wielkopolan w historycznym rozwoju i oglqdzie społecznym. Wprowadzenie do problematyki antologii, w: idem (wybór i oprac.), Etos Wielkopolan. Antologia tekstów o społeczeństwie Wielkopolski z drugiej połowy XIX i XX wieku, Wyd. Polskiego Towarzystwa Przyjaciół Nauk, Poznań 2015, s. 10.

${ }^{32}$ Warto przypomnieć, że słowo „kultura” pochodzi od łacińskiego czasownika „uprawiać” i dlatego w klasycznym ujęciu pojęcie kultury oznaczało uprawę. Początkowo uprawę roli (stąd agrokultura), a od czasu powstania Rozmów Tuskulańskich (45 r. p.n.e.) zaczęło być kojarzone z ,uprawą ducha”. Ich autor - Cyceron - jako czołowy przedstawiciel filozofii stoickiej podkreślał, że do wydania dobrych owoców duszy potrzebna jest uprawa, tzn. wyplenianie wad i przysposabianie cnót, które dokonać się mogą za sprawą dobrego wychowania i etycznego postępowania. I za to właśnie odpowiada kultura. 
kulturze. Otóż każda kultura musi wytwarzać taki właśnie mechanizm, dzięki któremu w ogóle możliwe jest jej istnienie i funkcjonowanie, jej materialne bytowanie. Mechanizm ten polega na wykształcaniu w świadomości jednostek przeświadczenia, że jedynie podjęcie systematycznej pracy daje szansę na życie we względnym dobrobycie. Przeświadczenie to wpajane jest zwłaszcza w procesie wychowywania kolejnych pokoleń w duchu poszanowania pracy. Zgodnie z nim jedynie pielęgnowanie określonych wartości, wzorców i postaw, jak na przykład podjęcie trudu nauki i ćwiczeń, wyrzeczenie, opóźniona gratyfikacja, systematyczność czy cierpliwość, umożliwić mogą jednostce dobre funkcjonowanie, a także stanowić szansę rozwoju. Proces ten, zwany enkulturacją, polega na długotrwałym nabywaniu przez jednostki kulturowych kompetencji i wyrabianiu w nich odpowiednich nawyków. Jest on tym skuteczniejszy, im wcześniej się rozpocznie, co oznacza, że decydujące znaczenie dla jego prawidłowego funkcjonowania ma instytucja rodziny, a potem szkoły, w których osobowość człowieka kształtuje się pod wpływem autorytetu rodziców, nauczycieli i wychowawców.

Ten sposób rozumienia etosu pracy (jako jednego z podstawowych mechanizmów kultury warunkującego prawidłowe funkcjonowanie każdej społeczności ludzkiej) umożliwia spojrzenie w nowy sposób na Huntingtonowską tezę o „zderzeniu cywilizacji”. Spoglądając na omawiane tutaj sprawy przez pryzmat etosu pracy, nietrudno dostrzec zarówno powody chińskiego sukcesu, jak i przyczyny zachodniego kryzysu. Skoro etos pracy stanowi tak ważny i powszechny element wyposażenia każdej kultury jako systemu mobilizującego (bądź demobilizującego) jednostki do działania, to staje się jasne, że pytanie o jego kondycję jawi się jako jedna z zasadniczych kwestii w zrozumieniu gospodarczej sytuacji współczesnych Chin i krajów Zachodu. O ile w odniesieniu do Chin mówić możemy - jak już wspominano - o całkowitej dominacji kultu pracy i powszechnym przeświadczeniu, że jedynie ona daje każdemu człowiekowi możliwość awansu społecznego, o tyle w większości rozwiniętych krajów Zachodu opinia o priorytetowym znaczeniu pracy w ludzkim życiu należy już do przeszłości. Można powiedzieć, że konfucjańskie podejście do pracy jako wartości samej w sobie czy rodziny jako podstawowej instytucji społecznej i gospodarczej, a także cześć dla rodziców i szacunek dla starszych, swoista gloryfikacja autorytetu i władzy, zapewnienie dziedzictwa i ciągłości, wyrzeczenie się własnych potrzeb, troska o innych, odłożona w czasie gratyfikacja czy potępienie bezczynności to tylko niektóre z żywotnych elementów silnie obecnych w mentalności współczesnych Chińczyków. Mając świadomość 
również i negatywnych stron ${ }^{33}$ chińskiego kultu pracy, znanego także pod nazwą guolaosi, trzeba przyznać, że stanowi on bezsprzecznie podstawę chińskiego systemu wartości i jedną z głównych przyczyn gospodarczego sukcesu tego kraju.

A jak współcześnie wygląda podejście do pracy na obszarze zasobnego Zachodu? Najkrócej mówiąc - źle. Nie ma tu, oczywiście, miejsca na choćby skrótowe przedstawienie różnych historycznych aspektów kształtowania się etosu pracy na gruncie zachodniej cywilizacji. Na pewno jednak należy wspomnieć o etyce protestanckiej, która u progu nowożytności wywarła wielki wpływ na mentalność mieszkańców Europy Zachodniej. Obszerne analizy na ten temat poczynione przez Webera, choć nie przez wszystkich do końca podzielane, wykazały, jak istotne znaczenie dla zbudowania zachodniej dominacji miała (lub mogła mieć) rozwijana przez Marcina Lutra koncepcja zawodu rozumianego jako powołanie, a zwłaszcza kalwińska nauka o predestynacji. Warto tu o nich nadmienić, zważywszy na fakt, że zdaniem Webera w XVI-wiecznej Europie Zachodniej za sprawą rozprzestrzeniającego się tam protestantyzmu doszło do powstania opisywanego wyżej przeświadczenia o konieczności podjęcia przez człowieka systematycznej (racjonalnej, jak powiedziałby Weber) pracy. To właśnie ona stała się źródłem życiowego sukcesu poszczególnych jednostek, a w skali społecznej - niejako przy okazji - przyczyną powstania kapitalizmu. Sukces ten, choćby w postaci zgromadzonych dóbr materialnych, nie był jednak dla protestanta celem samym w sobie, ale jedynie ,znakiem bycia wybranym”, czyli bycia przeznaczonym (predestynowanym) do zbawienia. Dlatego też życiowy sukces (np. w postaci zgromadzonego bogactwa) był traktowany przez protestantów jako przejaw bożego błogosławieństwa, umożliwiając tym samym jednostce „pozbycie się strachu o zbawienie”34. Z czasem protestancka żarliwość religijna stopniowo wygasała, a wiara w predestynację podzielana była w coraz mniejszym stopniu. W ten sposób purytańska asceza, w swej genezie i charakterze czysto religijna,

$33 \mathrm{~W}$ jednym z wielu prasowych doniesień na ten temat można przeczytać dość szokujące dane: „Pod koniec zeszłego roku chińska państwowa telewizja CCTV podała statystyki mówiące, że co roku w Państwie Środka na dolegliwości związane z przepracowaniem umiera ok. 600 tys. ludzi. To trochę więcej, niż liczy np. populacja Poznania” (H. Kozieł, Karoshi - azjatycka kultura pracy może cię zabić, „Rzeczpospolita” 29.04.2017, https://www.rp.pl/Plus-Minus/304279912-Karoshi---azjatycka-kultura-pracymoze-cie-zabic.html, dostęp: 13.02.2019.

${ }^{34}$ Por. M. Weber, Etyka protestancka a duch kapitalizmu, tłum. J. Miziński, Wyd. Test, Lublin 1994, zwł. rozdz. II. Etyka zawodowa ascetycznego protestantyzmu. 
zaczęła przekształcać się w świecki kodeks postępowania. Upowszechniony wówczas etos mieszczański, w tym szczególnie etos handlowy, były w praktyce życia codziennego tożsame z tym, co zostało wyżej określone jako etos pracy. Stanowiły one de facto rezerwuar tzw. cnót mniejszych, których przestrzeganie było warunkiem dobrego funkcjonowania człowieka w modernizującym się społeczeństwie zachodnim, a zwłaszcza w świecie kapitalizmu. To one składały się na wyznanie wiary Jankesa czy też inwentarz przekonań Amerykanów. Zdaniem jednego z największych spośród nich - Benjamina Franklina - cnót tych jest trzynaście, a mianowicie: umiarkowanie, wstrzemięźliwość, małomówność, porządek, zdecydowanie, skromność, pomysłowość, szczerość, sprawiedliwość, pokora, czystość, spokój oraz dziewictwo ${ }^{35}$.

Jednak to ascetyczne podejście do życia i wynikające z niego dość oczywiste przekonanie o konieczności podjęcia pracy jako jedynej drodze do dobrobytu uległo w świecie Zachodu w ciągu kilku ostatnich dekad znaczącej zmianie. Już w połowie lat siedemdziesiątych ubiegłego wieku Daniel Bell w głośniej pracy Kulturowe sprzeczności kapitalizmu pisał, że najłatwiej zmiany te „dostrzec można w społeczeństwie amerykańskim na przykładzie powstawania nowych zwyczajów robienia zakupów w gospodarce wysokiej konsumpcji i wynikającej stąd erozji etyki protestanckiej oraz postawy purytańskiej - dwóch zasadniczych kodeksów, na których wspierał się tradycyjny system wartości społeczeństwa mieszczańskiego w Ameryce. Właśnie załamanie się tej etyki oraz tej postawy [...] zdezawuowało przekonania sankcjonujące pracę i wynagrodzenie jako wartości społeczeństwa amerykańskiego”36. Kiedy zniknęła ascetyczna etyka protestancka, w sposób konieczny oznaczać

35 Znamienne jest to, że Weber w swojej pracy o protestanckich korzeniach kapitalizmu częściej cytuje Franklina niż np. Lutra, Kalwina, Knoxa, Zwingliego, Miltona, Baxtera czy też jakiegokolwiek innego reformatora. Co więcej, Weber, który uważa Franklina za najbardziej konsekwentnego wyraziciela zarówno etyki protestanckiej, jak i ducha kapitalizmu, z nieukrywaną satysfakcją przywołuje w swojej pracy dość obszerne fragmenty Mojego żywota tego właśnie filozofa, podkreślając, że nie zawierają one bynajmniej żadnych nawiązań do religii: „Pamiętaj, że pieniądz ma naturę polegającą na rozmnażaniu się i tworzeniu nowego. Pieniądz robi pieniądz, każdy nowy rodzi następny i tak dalej [...]. Im więcej jest pieniądza, tym więcej zysku w obrocie, a zysk ten rośnie coraz szybciej. Kto zabija maciorę, niszczy całe przyszłe potomstwo do tysięcznego pokolenia. Kto zabija pięcioszylingówkę, morduje (!) wszystko to, co można by z niej wyprodukować: całe góry funtów szterlingów” (M. Weber, Etyka protestancka..., s. 32).

${ }^{36}$ D. Bell, Kulturowe sprzeczności kapitalizmu, tłum. S. Amsterdamski, Wydawnictwo Naukowe PWN, Warszawa 1998, s. 90. 
to musiało stopniowy zmierzch etosu pracy. Za jego destrukcję nie jest jednak odpowiedzialny wyłącznie panujący obecnie na Zachodzie konsumpcjonizm oraz idący z nim w parze hedonizm. W społeczeństwach zachodnich coraz wyraźniej widoczne są procesy tzw. juwenalizacji kultury. Przejawiają się one we wszechobecnym kulcie młodości. Z jednej strony mieszkańcy świata zachodniego - w rezultacie postępów medycyny - żyją coraz dłużej, co powoduje starzenie się społeczeństwa w sensie chronologicznym. Jednak z drugiej strony pod względem postaw, zachowań, stylu życia i samodyscypliny ludzie ci żyją jak ich dzieci, a często nawet wnukowie, stając się w ten sposób niejako coraz młodsi. Możemy wręcz mówić o infantylizacji postaw i sposobów myślenia ludzi dorosłych. Proces ten daje się wyjaśnić za pomocą narzędzi psychologicznych oraz socjologicznych. Zgodnie z tym pierwszym infantylizm jest wynikiem patologicznego zatrzymania się jednostki ludzkiej na poziomie emocjonalnego rozwoju dziecka lub stanowi regres do tego stadium. W ten sposób jednostka broni się przed przerastającymi ją problemami wieku dorosłego ${ }^{37}$. Dochodzi wówczas do przedkładania tego, co łatwe, nad to, co trudne, tego, co proste, nad to, co złożone, impulsu nad rozwagę, zabawy nad pracę, przyjemności nad szczęście, natychmiastowej gratyfikacji nad długoterminową satysfakcję, ignorancji nad wiedzę, obrazu nad słowo, uczuć nad rozum itd. Natomiast w sensie socjologicznym proces ten polega na upowszechnieniu się tych postaw w sferze publicznej czy praktyce życia społecznego i w wyniku tego na ich całkowitej banalizacji oraz tabloizacji. Rządzi zasada „tu i teraz”, czymś powszechnym, a nawet pożądanym jest życie na kredyt, odczuwalny jest brak odpowiedzialności za siebie i swoich bliskich, a wszystko to w atmosferze niczym niezakłóconej, beztroskiej zabawy. Co jednak istotniejsze z punktu widzenia niniejszego artykułu, dominacja infantylizmu we współczesnej kulturze stanowi zagrożenie nie tylko dla funkcjonowania społeczeństwa i spójności kultury, ale także dla wydajności systemu kapitalistycznego. W opinii Benjamina Barbera, badacza opisywanych tu procesów i autora poczytnej książki Skonsumowani, zagrożenie to jest właśnie efektem zaniku tradycyjnych cnót i dominacji infantylizmu: „Etos infantylizmu kształtuje dziś ideologię i zachowanie

37 Opisując proces infantylizacji jednostki, można także odwołać się do dziedziny filozofii, a mianowicie do nietzscheańskiego mechanizmu resentymentu jako zabiegu odwrócenia czy zdyskredytowania wartości, którym nie jesteśmy w stanie sprostać. Prowadzi to w sposób nieuchronny do zastąpienia kultury wyrzeczenia kulturą hedonizmu. 
naszego radykalnie konsumenckiego społeczeństwa z równie przemożną siłą, jak czynnik nazywany przez Maxa Webera etyką protestancką kształtował kulturę przedsiębiorczości społeczeństwa kapitalistycznego w jego wczesnej, produkcyjnej fazie. Etos infantylizacji, wraz w ideologią prywatyzacji, handlowaniem markami i homogenizacją gustów, konsumencki kapitalizm, ale kosztem zarówno cnót obywatelskich, jak i cywilizacji, stwarza narastające zagrożenie dla samego kapitalizmu”38.

Jako dopełnienie obrazu erozji zachodniego etosu pracy niech posłużą wyniki badań przeprowadzonych kilka lat temu przez cenionego psychologa społecznego Philipa Zimbardo. Okazuje się na przykład, że w Stanach Zjednoczonych „w ósmej klasie [...] jedynie 20\% chłopców sprawnie pisze, 24\% zaś sprawnie czyta, w porównaniu z 41\% dziewcząt, które dobrze piszą, i 34\% dziewcząt, które dobrze czytają"39. Te oraz wiele innych wyników badań, które przywołuje autor w cytowanej książce, pozwala mu stwierdzić, że po raz pierwszy w historii Stanów Zjednoczonych współczesne pokolenie jest gorzej wykształcone od swoich rodziców. Ma to, jego zdaniem, bezpośrednie przełożenie nie tylko na stopniowe zanikanie etosu pracy, czy choćby szacunku do niej, ale także na systematycznie spadającą gotowość do podjęcia jakiejkolwiek pracy przez osoby młode. Kryzys ten jest widoczny zwłaszcza wśród młodych mężczyzn. Zimbardo pyta wprost: „Gdzie w umysłach facetów zagubiła się protestancka etyka pracy? W latach 2000-2010 - kontynuuje autor odsetek nastolatków na rynku spadł o 42\%, a liczba zatrudnionych osób w wieku od dwudziestu do dwudziestu czterech lat obniżyła się o 17\%”"

${ }^{38}$ B.R. Barber, Skonsumowani. Jak rynek psuje dzieci, infantylizuje dorosłych i połyka obywateli, tłum. H. Jankowska, MUZA SA, Warszawa 2008, s. 10.

${ }^{39}$ P.G. Zimbardo, N.S. Coulombe, Gdzie ci mężczyźni?, tłum. M. Guzowska, Wydawnictwo Naukowe PWN, Warszawa 2015, s. 28.

40 Ibidem, s. 35. Alarmujące dane docierają nie tylko ze Stanów Zjednoczonych. Zimbardo przytacza wyniki badań pochodzących z najbardziej rozwiniętych krajów i gospodarek Zachodu, pisząc: „W Wielkiej Brytanii odsetek bezrobotnych wśród osób w wieku 15-24 lat wynosi 21, niemal 5 punktów procentowych więcej niż średnia 16,3\% podawana przez OCED. Bezrobocie wśród mężczyzn w wieku od dwudziestu pięciu do trzydziestu czterech lat w Stanach Zjednoczonych jest ponad dwukrotnie większe niż w 1970 roku. Inne kraje, takie jak Włochy, Francja, Hiszpania, Szwecja czy Japonia, doświadczyły ponad pięciokrotnego wzrostu poziomu bezrobocia wśród młodych mężczyzn. OECD odnotowuje, że średnia stopa bezrobocia wśród mężczyzn na przełomie drugiej i trzeciej dekady życia skoczyła z 2\% w 1970 do 9\% w 2012 roku. To ogromna zmiana, pokazująca, że miliony młodych mężczyzn nie pracują" (ibidem). 


\section{Podsumowanie}

Reasumując powyższe refleksje na temat aktualności postawionej przed ćwierćwieczem przez Huntingtona tezy o zaostrzającym się konflikcie pomiędzy cywilizacjami, powiedzieć można, że jesteśmy świadkami jego eskalacji. Wraz z końcem sowieckiego komunizmu i upadkiem żelaznej kurtyny skończyła się też zimna wojna i stanowiący jej efekt dwubiegunowy podział świata. Powstały w ten sposób nowy układ sił charakteryzuje się wielobiegunowością oraz dużą dynamiką zmian. Z jednej strony zanikły dotychczasowe podziały i granice, ale z drugiej - powstały ich nowe odpowiedniki. W wielu przypadkach są one oparte na różnicach kulturowych i - co gorsza - odwołują się do stereotypów, uprzedzeń oraz uśpionych animozji. Na naszych oczach spełniają się też przewidywania Huntingtona odnośnie do słabnącej roli Zachodu. Coraz głębsze jego problemy wynikają przede wszystkim z kryzysu tożsamości i erozji sfery wartości. Te ostatnie, stanowiąc szeroko pojęty kulturowy rezerwuar, nie dostarczają jednostkom wystarczająco silnych bodźców motywujących do podejmowania codziennego trudu i wysiłku związanego chociażby z uzyskaniem wykształcenia czy nabycia umiejętności niezbędnych do podjęcia wykwalifikowanej pracy zawodowej. Mówiąc wprost, na gruncie zachodniej cywilizacji praca przestaje być postrzegana jako warunek względnie dostatniego życia. Zwłaszcza wśród młodego pokolenia zanika oczywiste dotąd przeświadczenie, że jedynie poprzez systematyczną pracę i towarzyszące jej elementy (takie jak wykształcenie, praktykowanie, treningi czy ćwiczenia) można osiągnąć satysfakcjonujący poziom życia, który będzie wyższy od poziomu życia rodziców. Trudno nie zauważyć, że wiele współczesnych zachodnich społeczeństw w znaczącym stopniu konsumuje zasoby wypracowane przez poprzednie pokolenia. W rezultacie kryzys zachodniej kultury objawia się licznymi negatywnymi zjawiskami w rozmaitych dziedzinach życia społecznego, ale także - co istotne z punktu widzenia niniejszego artykułu - skutkuje słabnącą konkurencyjnością zachodnich gospodarek. Idące z tym w parze problemy demograficzne i - najkrócej mówiąc - nieuchronny deficyt płatników przyszłych świadczeń emerytalnych próbuje się w wielu rozwiniętych krajach Zachodu rozwiązać poprzez prowadzenie otwartej polityki imigracyjnej. Jednak rzeczywistość na naszych oczach brutalnie weryfikuje słuszność tej polityki, a ponadto jej kierunek potwierdza tylko, że zachodnia cywilizacja, posiłkując się „zastrzykiem świeżej krwi” z zewnątrz, znajduje się w głębokim kryzysie. 
Innymi słowy, etos pracy jako istotna część kulturowego wyposażenia jednostki ma, jak się wydaje, decydujące znaczenie dla podejmowania przez nią aktywności gospodarczej. Porównanie kondycji współczesnej gospodarki chińskiej z gospodarkami zachodnimi wypada zdecydowanie na korzyść tej pierwszej. Oczywiście, przyczyn tego stanu rzeczy doszukiwać się można wśród różnych czynników i zapewne rozpatrywać je należy na wielu płaszczyznach. Jedną z nich jest bez wątpienia płaszczyzna kulturowa. Zestawiając na tej właśnie płaszczyźnie najistotniejsze cechy popychające ludzi, zwłaszcza młodych, do działania w celu poprawy bytu własnego i własnej rodziny, możemy lepiej zrozumieć powody powiększającego się dystansu między Chinami a Zachodem. System wartości, który przez wieki zapewniał światu zachodniemu dominację, staje się coraz bardziej niewydolny i prezentuje się w tym zestawieniu po prostu źle. Zwłaszcza na tle żywotnych (zarówno pod względem kulturowym, jak i demograficznym) cywilizacji chińskiej czy islamskiej Zachód jawi się jako formacja, jeśli nie chyląca się ku upadkowi, to na pewno przeżywająca ogromny kryzys tożsamościowy. Jak wiadomo, życie nie znosi próżni i dlatego obszary zdominowane dotąd przez cywilizację zachodnią stopniowo stają się domeną cywilizacji niezachodnich. To właśnie one dostarczają kulturowych bodźców, które lepiej motywują jednostki do działania, a społeczeństwom stwarzają większe szanse rozwoju. I właśnie w tym kulturowym, a mówiąc ściślej - „etosowym”, sensie jest to przejaw nowej odsłony „zderzenia cywilizacji”, o której przed ćwierć wiekiem pisał Samuel Huntington.

\section{Literatura}

Arystoteles, Etyka nikomachejska, tłum. D. Gromska, Państwowe Wydawnictwo Naukowe, Warszawa 1982.

Barber B.R., Skonsumowani. Jak rynek psuje dzieci, infantylizuje dorosłych i połyka obywateli, tłum. H. Jankowska, MUZA SA, Warszawa 2008.

Bell D., Kulturowe sprzeczności kapitalizmu, tłum. S. Amsterdamski, Wydawnictwo Naukowe PWN, Warszawa 1998.

Berger P.L., Rewolucja kapitalistyczna, tłum. Z. Simbierowicz, Oficyna Naukowa, Warszawa 1995.

Fukuyama F., Koniec historii i ostatni człowiek, tłum. T. Bieroń, M. Wichrowski, Wyd. Znak, Kraków 2017.

Huntington S.P., Zderzenie cywilizacji i nowy kształt ładu światowego, tłum. H. Jankowska, MUZA SA, Warszawa 2004.

Kołodko G., Czy Chiny zbawiq świat, „Rzeczpospolita” 16.05.2017.

Kozieł H., Karoshi - azjatycka kultura pracy może cię zabić, „Rzeczpospolita” 29.04.2017. 
Landes D.S., Bogactwo i nędza narodów. Dlaczego jedni sq tak bogaci, a inni tak ubodzy, tłum. H. Jankowska, MUZA SA, Warszawa 2000.

Molik W., Etos Wielkopolan w historycznym rozwoju i oglądzie społecznym. Wprowadzenie do problematyki antologii, w: idem (wybór i oprac.), Etos Wielkopolan. Antologia tekstów o społeczeństwie Wielkopolski z drugiej połowy XIX i XX wieku, Wyd. Polskiego Towarzystwa Przyjaciół Nauk, Poznań 2015.

Poznański K., Ekonomia jako etyka: podejście konfucjańskie, tłum. M.A. Michalski, w: E. Mączyńska, J. Sójka (red.), Etyka i ekonomia. W stronę nowego paradygmatu, PTE, Warszawa 2017.

Weber M., Etyka protestancka a duch kapitalizmu, tłum. J. Miziński, Wyd. Test, Lublin 1994.

Weber M., Taoizm i konfucjanizm, w: idem, Socjologia religii. Dzieła zebrane. Etyka gospodarcza religii światowych, cz. 1, tłum. T. Zatorski, Zakład Wydawniczy Nomos, Kraków 2006.

Zimbardo P.G., Coulombe N.S., Gdzie ci mężczyźni?, tłum. M. Guzowska, Wydawnictwo Naukowe PWN, Warszawa 2015. 
